\title{
The changing role of ports as locations for logistics activities
}

\author{
Larissa M. van der Lugt" and Peter W. de Langen*"
}

\begin{abstract}
Ports are often seen as engines behind regional economic development, because ports attract a variety of economic activities. This paper focuses on the role of ports in global supply chains and the opportunities to attract new economic activities in logistics. The central argument of the paper is that the role of ports as a location for logistics activities evolves with the evolution of logistics concepts. Evidence from West Europe is discussed. With the evolution of logistics concepts towards central coordination and more decentralized physical distribution, ports will see its multinational function diminish, eventually replaced by logistics activities with a more regional function and stronger integrated with production activities. Ports then have to face the competition from inland locations for value added logistics activities. The case of logistics developments provides a basis for analysing the increasingly important questions "What logistics activities ports can attract?" and "What is the appropriate strategy to result in this?"
\end{abstract}

Keywords: ports, logistics, supply chains, regional economic development, South Korea

\section{Introduction}

Ports are often seen as engines behind regional economic development, because ports attract a variety of economic activities. Ports can be considered to be more than just a node in a transport system; ports are also clusters of economic activity (De Langen, 2004). This is illustrated by the fact that the performance of ports is increasingly measured in added value instead of throughput tons (or containers). In line with a definition of Notteboom (2000) we define a port in such a way that this cluster effect is made clear: "A

Submission Date : 8/3/2005 Acceptance Date : 12/1/2005

"Corresponding Author : Professor, School of Economics, Section Regional, Port and Transport Economics, (RHV BV) P.O. Box 17383000 DR Rotterdam Room H12-11 Erasmus University, Netherlands, Phone: + 3110408 1410, Fax: +31 10408 9156, E-mail: vanderlugt@ few.eur.nl

${ }^{*}$ Professor, Rotterdam School of Economics, Section Regional, Port and Transport Economics P.O. Box 17383000 DR Rotterdam Room H12-13 Erasmus University, Netherlands, : + 31104081678 Fax: +31104089156 
seaport is an area with maritime and hinterland access that has developed into a logistics and industrial centre, playing an important role in global industrial and logistics networks.".

In this respect a relevant question is "How can the potential of a port in attracting logistics activities to its area be assessed?" The argument presented in this paper is that changing strategies of globalising manufacturing companies drive the evolution of logistics concepts. The role a port location can play evolves with these changing strategies and the changing nature of logistics concepts.

We start with an analysis of the evolution of globalization strategies of multinational manufacturing companies (MNC's). We then relate this to the evolution of logistics concepts. The third step is the assessment of the potential role of a port in different logistics concepts. A few recommendations based on developments in a Europe are discussed in the next section, followed by a short overview of challenges and opportunities for South Korean ports.

\section{Strategies of Multinational Companies: Towards Supply Chain Management.}

The strategies of many multinational companies (MNCs) have changed from focused on market development to a focus on logistics efficiency and costs, to a focus on both market development as logistics efficiency and costs, i.e. the creation of competitive advantage (see figure 1).

Figure 1. Changing strategies of MNCs

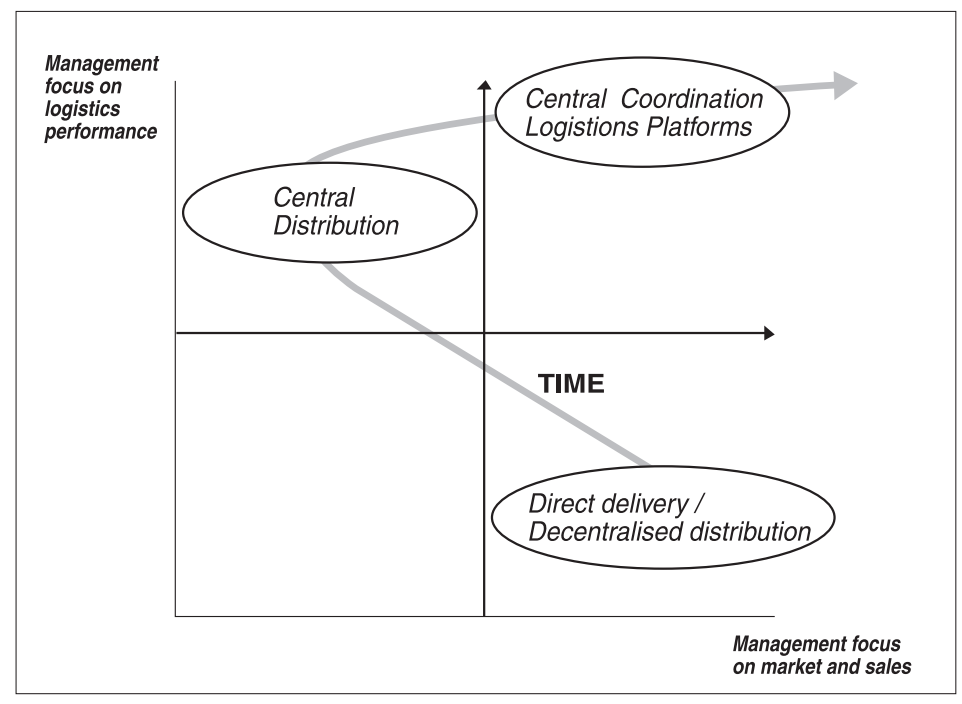

\footnotetext{
${ }^{1}$ Notteboom defines a seaport as " a logistic and industrial centre of outspokenly maritime nature that plays an active role in the global transport system and that is characterised by a spatial and functional clustering of activities that are directly and indirectly involved in "seamless" transportation and information processes in production chains."
} 
Manufacturing firms started to globalize already after the industrial revolution, mainly to expand their markets and reduce production costs. The last decades of the 20th century, this process accelerated, due to the liberalization of trade (the GATT agreement in 1948 and later reductions of trade tariffs and barriers), changes in transport technology (introduction of the container in the 1960s) and changes in communication technology (e.g. telephone and internet).

Globalization strategies of firms can be explained by two motives: the market expansion motive and the factor-input motive (Fawcett, 1992). The market expansion motive focuses on increasing 'foreign sales'. The primary objective of the factor-input strategy is the enhancement of a firm's competitive position in its home market by shifting the production activities to various regions in the world, based on cost advantages. In reality, multinational firms combine both strategies. The truly global corporation integrates both strategies to improve its competitive position in world markets (Fawcett, 1992).

The ongoing globalization was a strong impulse for increased attention for logistics management. Logistics became a 'boardroom issue' for many MNC's in the 1980s. Studies of Bowersox (1989), Cooper (1990) and Fawcett (1990) highlighted the need for more attention for logistics: facility location planning, fleet selection, inventory management, vehicle routeing, and foremost an integrative approach to these items.

Over the last decade the focus on logistics management has been "replaced" by a focus on supply chain management, mainly because firms gradually became aware of the fact that logistics is not merely an area for cost improvements but rather a source for competitive advantage (Panayides, 2004, Novak et al, 1994). Some scholars see supply chain management as just a new term for logistics management (Larson and Halldorsson, 2004), but in this paper we adopt the view that supply chain management differs from logistics management in the sense that supply chain management starts with customer requirements and focuses on the alignment of all activities needed in the supply chain to create competitive advantage for serving these customers. Logistics management focuses on the alignment of the activities needed to process and transform materials and goods to meet given supply chain requirements. Thus defined logistics management is a specific part of supply chain management and is strongly influenced by changes in supply chain strategies.

The design of supply chains has evolved over the last decades, due to ever changing customer requirements related to price, quality, speed, reliability, flexibility and customer service (Chikan, 2001). Innovations in design, organization and operation of supply chains have taken place rapidly. Important changes in this respect are the increasing integration of production and logistics within supply chains, the ongoing focus on outsourcing strategies and formation of supply networks, the shift of making the products country and client specific closer to the market (postponed manufacturing) and a change within industries from mass production to flexible (batch) production.

The integration of production and logistics and outsourcing strategies results in a clearer distinction between firms. A limited number of firms establish themselves as 'brands' with product development and customer service as core competencies (examples include Nike and Daimler- Chrysler), firms with effective control of logistic and production chains as core competency (logistics service providers) and companies with as 
core competencies the efficient operation of activities that form part of the logistics and production chains (e.g. plant management and transport companies) (see Welters and De Langen, 2003). This division of firms is closely related to the distinction between integrators, first tier and second tier suppliers. Figure 2 illustrates the structure that governs this division of firms in supply chains.

Some MNCs (still) operate as vertically integrated corporate hierarchies, but there is a clear trend towards 'inter-firm division of labour' in global supply chains. In this model, different firms engage in different activities. This division of tasks in global supply chain leads to an increased need for 'coordination beyond price' between the firms that are active in parts of the supply chain. Consequently, supply chain networks frequently emerge with close coordination between different firms engaged in production, logistics and transport (Chikan, 2001).

For logistics service providers the changes in supply chain design imply that their role changes. Some of the logistics service provider succeeds in attracting more sophisticated value added activities, while others lack the required scale and capabilities. As a result, concentration and internationalization characterise the logistics industry. The increasing requirements of customers drive new product requirements and the customer service requirements. These new requirements are 'passed on' to logistics service providers.

Figure 2. Governance structure of supply chains

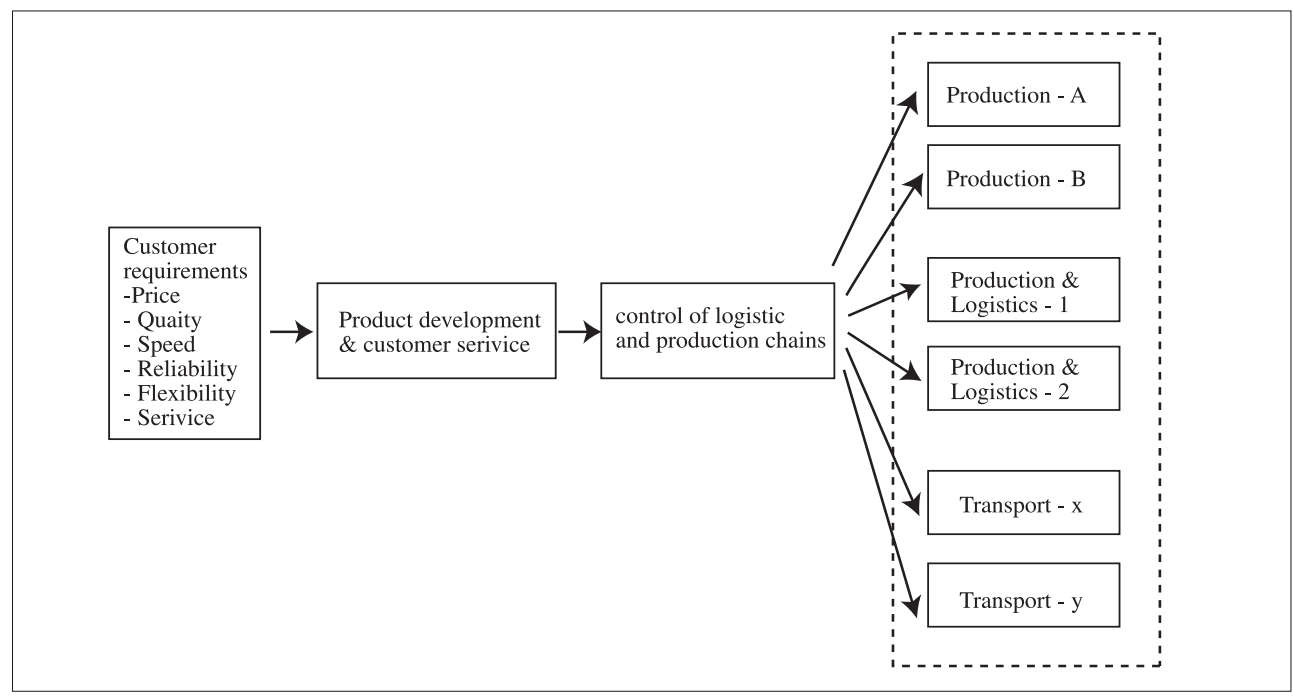

III. Evolution of Logistics Concepts in Europe

The developments in supply chains have led to an evolution of logistics concepts of MNC's servicing the European continent. Both concepts related to European imports (distribution related logistics concepts) and European exports (consolidation related logistics concepts) are discussed. 
Concerning the distribution related logistics concepts in Europe over the last two decadesennia an evolution of concepts can be seen. Multinational manufacturing companies that have extended their markets to Europe and that are faced with changing customer requirements have gone through an evolution of logistics concepts for their European distribution. Various authors distinguish groups of logistics concepts that have evolved over time (Abrahamsson, 2003; Ruijgrok \& and Kuipers, 2001; Buck Consultants, 1999; HIDC, 1994). Based on these publications three different concepts that have evolved in Europe are identified.

In the first stages of internationalisation products are delivered directly to different markets in Europe. This concept is characterised by national distribution centres or national importers with storage locations, because in this stage, different countries in Europe were (considered as) different markets, with different consumer preferences, standards and regulatory requirements. In this concept, transport is also decentralised: the various markets are served independently by air or sea.

With the emerging focus on logistics efficiency, and ongoing European integration Central European Distribution concepts emerged. These concepts are characterised by a single physical central storage and distribution location where value added activities can take place. Such a single European distribution center (EDC) serves all European markets. Delivery takes place directly from the central distribution centre or via regional crossdocking centres. Intercontinental transport is centralized to the EDC, mostly by sea.

The combined focus on logistics efficiency and market expansion driven by customer requirements - the core of supply chain strategies of most MNCs - leads to central coordination, but not necessarily central distribution, and in some cases to the development of logistics platforms. A logistics platform originates from a firms' internal cooperation between marketing development and logistics development and combines the operational management and control of logistics activities with design, development and renewal activities of the logistics system (Abrahamsson, 2003). Logistics platforms both have an operational and strategic function. Logistics platforms emerge in a situation where the business environment is dynamic and flexibility of supply chains and production facilities is required. Concepts like postponed manufacturing, vendor managed inventory systems, combined with transport concepts like direct delivery, cross-docking, and merge in transit are applied in a network of various logistics facilities with multinational or regional service areas, steered and controlled from one (virtual) location and supported by sophisticated information systems (Abrahamsson, 2003). Figure 3 illustrates the three base concepts. 
Figure 3. Evolution of import related logistics concepts

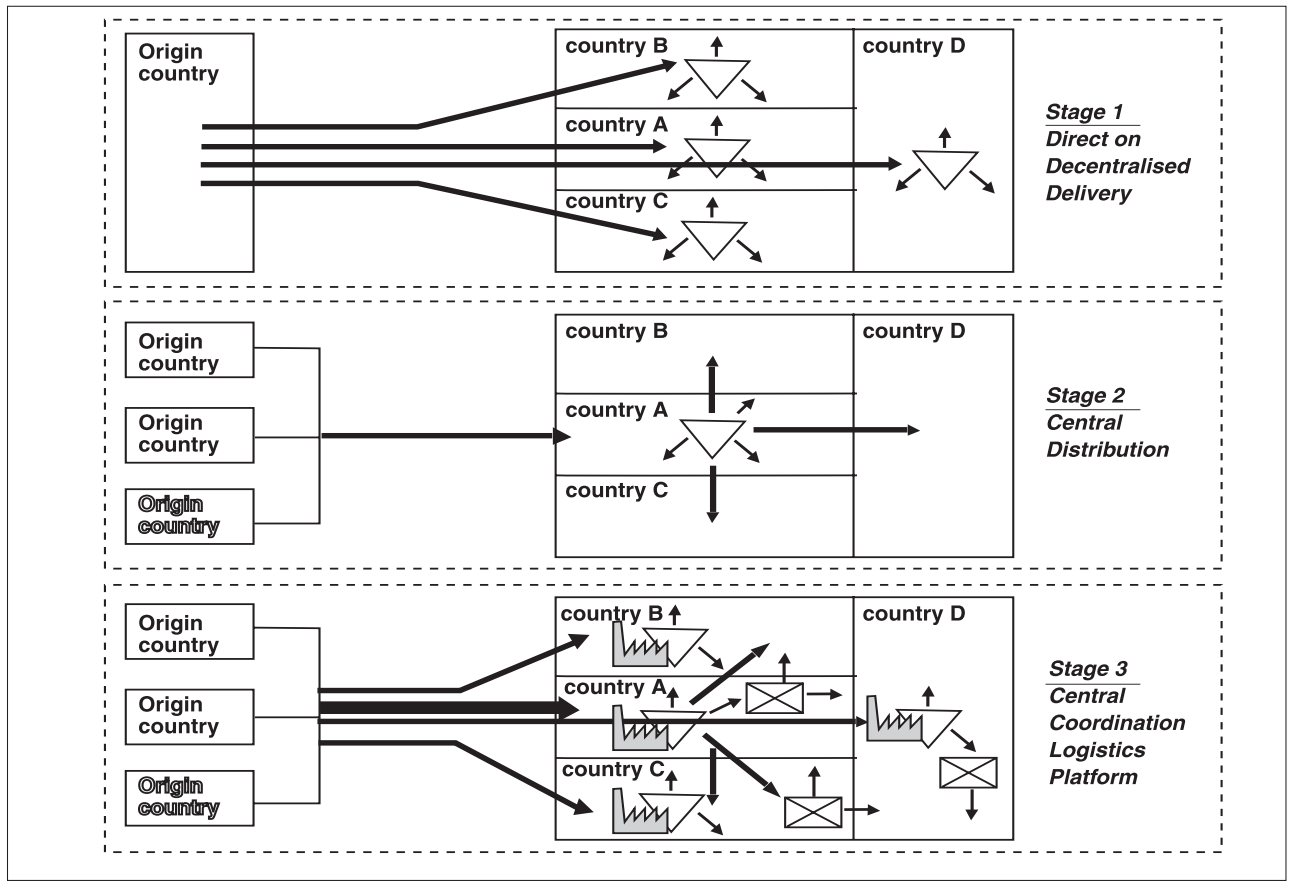

Figure 4 further illustrates the evolution of logistics strategies: first firms focus on market expansion, then on logistics efficiency and finally on both aspects.

Figure 4. Emergence of distribution related logistics concepts related to managerial focus

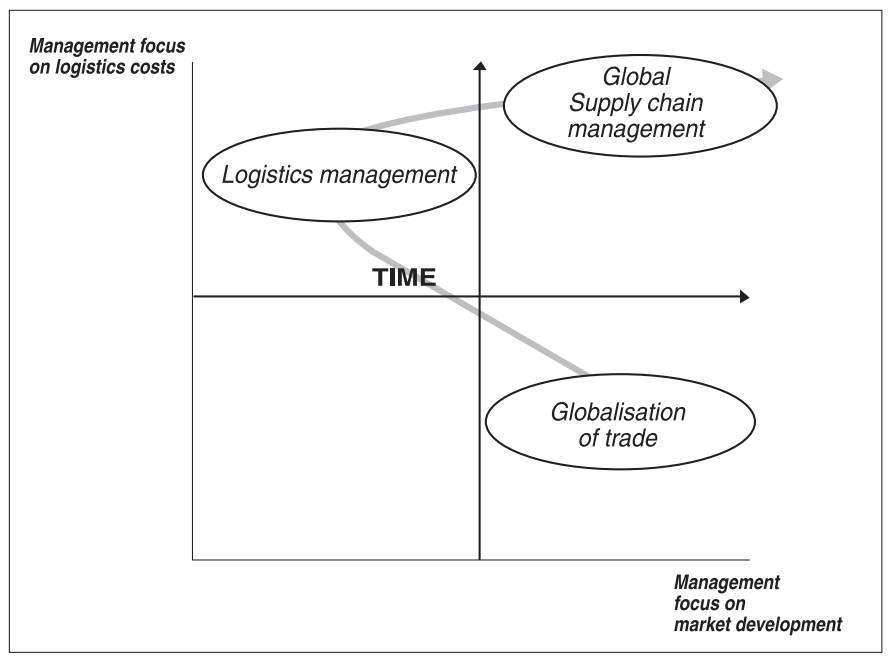


The evolution of logistics concepts does not correspond exactly with periods in time. Some firms have adopted 'stage three' strategies relatively early, while other firms (still) have a 'stage two' strategy. This depends both on the product characteristics and positions in markets. However over time a sequential emergence of new concepts can be seen resulting in a mix of alternatives that prevail at the same time. Keeping in mind the variety of strategies of MNCs, the trend as illustrated in figure 4 is widely accepted. In Europe the second concept emerged from the 1980s onwards especially inspired by Toyota's production philosophy ${ }^{2}$. Not until the 1990s centralised logistics became the rule rather than the exception. The emergence of logistics platforms, steering, designing and renewing complete logistics systems with a network of facilities, centrally managed and controlled (Abrahamsson et al. 2003) is of a more recent date and still not widely introduced.

Much less attention is paid to consolidation related logistics in which not European but overseas markets are serviced. The main reason for this is that Europe (and also the USA) ${ }^{3}$ is traditionally a distribution area rather than a consolidation area. Buck (1999) distinguishes two logistics concepts for outgoing flows. The first one is the direct delivery concept in which FCL containers go directly from the European location via the port to the country of destination. The second concept is the and Consolidation of export flows. Production locations do not produce final goods, but produce specific parts. Consolidation of LCL containers takes place before the transport to the country of destination. This consolidation function can be located either in the port region or in the hinterland, centrally located towards the production locations.

For export logistics the main activities are consolidation of LCL containers, consignment treatment, packaging and stowage, temporary storage, and customs clearing. These 'export logistics' systems are less dynamic: most MNCs with exports from Europe have streamlined these exports flows and mostly focus on re-locating, manufacturing activities to regions with more favourable manufacturing conditions (e.g. wage level, regulations).

\section{Port Areas As locations for Logistics Activities}

In this section we analyse whether ports can play a role in the various logistics concepts. Narrowly defined, a port is a node in transport networks. On one side there are maritime networks, on the other side the hinterland networks, and in between the port as trans shipment (and storage) location. In a broader approach, ports can be defined as a land area with maritime and hinterland access that has developed into a logistics and industrial centre, playing an important role in global industrial and logistics networks (Notteboom, 2001; De Langen, 2004).

A port often serves as a location for value added logistics activities. In most ports, logistics activities generate more employment thant terminal activities (De Langen, 2004).

${ }^{2}$ Focus on productivity and the maximisation of resource utilities

${ }^{3}$ And in these two regions logistics has undergone its major sophistication 
Furthermore, growth opportunities in terms of employment and value added are more substantial in logistics than in transport and terminal operations. These two industries have consistently become less labour-intensive over the last three decades. Thus, the economic importance of a port is largely determined by its success in attracting additional economic activities. Activities in logistics are in most ports the most attractive growth options for ports. However, in order to attract logistics activities, ports need to provide an attractive business climate. Most ports are investing to this end, with mixed results.

Ports can provide space for warehouses and other logistics related facilities and services. The central issue is to what extend a port area can be an attractive location for value adding logistics activities and how can these logistics activities be attracted? We argue that ports are not merely re-active to changes in supply chain strategies, but can develop strategies to improve their attractiveness for logistics activities. If such improvements are effectively timed, initial success in attracting logistics activities may be self re-enforcing due to the presence of agglomeration economies. Perhaps the best example of such strategies are investments to create special 'logistics zones' and in some cases 'free trade zones' in port areas.

Looking at the evolution of distribution related logistics concepts in Europe, the following conclusions about the potential role of a port with respect to value added logistics activities can be drawn:

In the 'direct or decentralised delivery' concept there is limited possibility for ports to attract and develop value adding logistics activities. Ports may attract distribution facilities, but since distribution is limited to the national market, the dominant transport mode is road transport. Thus, the advantages of ports in terms of transport services by rail, shortsea and inland waterway are not important. Consequently, most logistics facilities are not located in ports.

In the second concept - central distribution centers - ports are potential locations for these central distribution centres. This is illustrated in Europe by the fact that the port of Rotterdam has succeeded in attracting a substantial part of the European (central) distributions centres that are established in Europe. The conditions for attracting these EDCs were:

- Availability of space, located centrally to the markets;

- Liberalised transport and logistics sector;

- Well-developed system of hinterland connections;

- Well-developed labour pool with specialisation in logistics;

- Clear legislative and regulatory framework and

- Attractive business climate (customs, ICT, supporting services).

Other ports have also developed strategies to attract 'central distribution facilities'. Examples include Antwerp, that provides location advantages similar to those of Rotterdam, Barcelona, where a large distribution zone was developed and a 'dry port' in Southern France was opened, Panama, where large logistics zones are developed and Jebel Ali, where a 'free trade zone adjacent to the port was developed and has attracted a substantial number of global logistics service providers.

In the third concept no physical centralisation of storage and logistics activities takes place, but management and control are centralised. A port faces the risk of loosing its 
multinational (European) logistics function. Ports do have an opportunity to attract the newly integrated production-logistics facilities, but merely with a regional scope. The geographical area served by such facilities is determined by the efficiency and effectiveness of the hinterland transportation system, since lead time is more important than geographical distance (Abrahamsson, 2003. However, ports will face competition from other regional ports and inland locations and will only be attractive when they are considered as logistical A-locations. In comparison to attracting EDCs (phase 2 facilities), additional location characteristics that are required to attract flexible, integrated logistics facilities are:

- A well educated labour force, with up-to-date logistics knowledge;

- A well functioning market for logistics facilities and

- A strong supplier base of firms that can be contracted to provide specialised services, to further increase the flexibility.

Table 1 summarises the main arguments presented in this paper, by relating MNC strategies to logistics concepts to the potential role of port locations for value added logistics activities and important location characteristics.

Table 1. Rrelation of managerial focus, business practices, logistics concepts and role of port location

\begin{tabular}{|c|c|c|c|}
\hline Strategies of MNCs & Logistics concepts & Role of port location & $\begin{array}{l}\text { Main required location } \\
\text { characteristics }\end{array}$ \\
\hline Market development & $\begin{array}{l}\text { Direct delivery / } \\
\text { decentralised } \\
\text { distribution }\end{array}$ & $\begin{array}{l}\text { Limited regional } \\
\text { function: transit, } \\
\text { regional distribution } \\
\text { centres }\end{array}$ & $\begin{array}{l}\text { Available land. } \\
\text { Good accessibility by road } \\
\text { Well functioning and } \\
\text { competitive road } \\
\text { transport sector }\end{array}$ \\
\hline Logistics efficiency & Central distribution & $\begin{array}{l}\text { Extended multinational } \\
\text { function: Establishment } \\
\text { of Central Distribution } \\
\text { Centers }\end{array}$ & $\begin{array}{l}\text { Multi-modal transport } \\
\text { services } \\
\text { Central location in } \\
\text { larger region } \\
\text { Well trained labour pool }\end{array}$ \\
\hline $\begin{array}{l}\text { Both market } \\
\text { development and } \\
\text { logistics efficiency, } \\
\text { i.e. creating } \\
\text { competitive } \\
\text { advantage }\end{array}$ & $\begin{array}{l}\text { Central coordination / } \\
\text { logistics platforms }\end{array}$ & $\begin{array}{l}\text { Diminishing } \\
\text { multinational function, } \\
\text { more regional function: } \\
\text { attraction of integrated } \\
\text { production/ logistics } \\
\text { facilities with regional } \\
\text { function }\end{array}$ & $\begin{array}{l}\text { Educated labour force } \\
\text { Logistics knowledge } \\
\text { Flexible facilities } \\
\text { A strong supplier base for } \\
\text { specialised logistics } \\
\text { services }\end{array}$ \\
\hline
\end{tabular}


The role of European ports in consolidation related logistics concepts is not as extensive as in import logistics. Ports can serve as points of consolidation with activities like preparing documents, dealing with customs, but and value added logistics activities, mainly consolidation of cargoes. Such activities are not a growth market for most ports.

\section{Port Logistics in Developing Regions}

In this paper we analysed the development of logistics concepts in Europe and the role that a port plays in these logistics concept. The insights of Europe may be relevant for other regions in the world. However one cannot simply translate concepts from one region to another. Regions or countries show different characteristics in their economic function, in their political and institutional environment and in their geographical and infrastructural situation.

In international economics it is a general observation, that over time regions or countries show different paths of development. There is continuous shift of sophistication of production and logistics from one country to another. However due to the globalisation regions are influenced by the development in other regions. A region that lags behind for instance in technological development will not show the same path of development, but will be affected by the technological innovations that are already available from this other regions. Thus the various logistics concepts that have evolved in Europe may be implemented more rapidly or with additional innovations in other regions. Two comments on this are relevant. First, the economic integration of a number of countries into one single market is more advanced in Europe than in a number of other regions (e.g. Asean, Mercosur). When integration occurs in these regions as well a similar trend towards central distribution may emerge. Second, the size of the European market is large. Investments in postponed manufacturing or flexible, integrated logistics facilities are viable in this market earlier than in other smaller regional markets.

The different aspects as described above should be taken into account while applying the insight on the evolution of logistics concepts in Europe and the role a port could play in this to other regions in the world. The following questions are relevant in this respect:

- Is international trade substantial and can growth be expected?

- What role does a region mainly play in global supply chains; manufacturing, assembly, customisation or final distribution?

- To what extent are requirements met for the development of different logistics concepts within the region?

These requirements are the existence of a market oriented logistics sector, illustrated by the presence of global logistics service providers ${ }^{4}$ and the possibility to develop efficient cross-border logistics.

${ }^{4}$ LSPs like Excel, Schenker Logistics, Nippon, Geodis, Menlo worldwide logistics, Panalpina, ABX, etc. 


\section{The Case of South Korea}

This paper concludes with some considerations for the development of logistics in South Korea. South Korea is especially interesting because of its central location between two large economies (China and Japan) and the fact that the Korean economy is affected strongly by the growth of the Chinese economy. For this reason, Korean policy makers search for new growth opportunities for their country and have identified logistics as one of those opportunities (Lee and Oum, 2001; Rimmer, 2003). Given this background, an analysis of logistics systems in Korea is relevant. Some insights on South Korea's function in global transport and logistics chains, its political and institutional situation, its business climate and its infrastructural situation are provided below.

- The Asian market is a developing and growing market, mainly production and export driven. Increasingly production and also assembly is moved from western countries to Asian (and Eastern European) countries;

- The most substantial Korean logistics function is consolidation, with a focus on outbound flows;

- China is opened up, leading to sharply increasing trade flows between China and other countries, including Korea;

- The Asian countries are not strongly integrated in a larger trade zone. Harmonisation of law, customs etc. is limited;

- The Korean government has a strong focus on developing the country into a major logistics hub for Northeast Asia (Y-T Chang, 2002);

- In Korea the logistics market mainly consists of medium-size local based companies. However this is changing as more MNCs locate in South Korea (e.g. DHL with a warehouse facility dedicated to BMW) and

- Infrastructure is in development but still not at the right level. Good international rail and inland navigation connections are missing, while road traffic suffers from congestion.

In order to attract companies to value added logistics zones knowledge should be build on the function South Korea can fulfil in the global supply chains. Based on the lessons from Europe, we argue that for export flows, South Korea could develop consolidating and assembly activities based on the facts that MNCs have moved their production locations towards Asia and are now in the process of moving also their basic assembly activities to lower wage countries regions like Asia and Eastern Europe. Besides, China's logistics sector is not yet very liberalised and efficiently working (although improvements can be expected following China's role in the WTO). Export flows from China are not very regular and reliable. This gives rise to a potential for a consolidation function in South Korea (Ruijgrok and Kuipers, 2001).

For import flows, value added logistics activities with a regional scope (South Korean and partly China) can be attracted to the port. Whether the port's logistics activities zones can attract value added activities with a multinational scope depends on:

* Development of consumer markets in China and North Korea; 
- Logistics strategies of companies servicing Japan;

- Competitive position of South Korea vis-a-vis China and Japan;

- Openness of both North Korea and China for harmonisation of trade within the region and

- Development of infrastructural connections to China (e.g. shortsea or by rail through North Korea).

\section{Conclusions}

In this paper the evolution of logistics concepts over time and the changing roles of ports as locations for value added logistics activities were discussed, based on a literature review and observations in Europe especially the Netherlands. The role of a port as location for value added logistics activities co-evolves with logistics concepts for distribution and consolidation. These concepts have changed as a result of changing strategies of MNC's from a focus on market expansion, to a focus on logistics efficiency and finally to a combination of both.

The role of ports for value added logistics activities might diminish because of a shift from an multinational function to a more regional function. This is caused by the ongoing development of supply chain systems, in which central coordination and logistics platforms replace central distribution. An interesting question that arises is the speed of the developments of multinational manufacturing and logistics firms towards sophisticated supply chain systems and the ability of ports to position themselves as attractive partners in changing supply chains. Ports with that ability will need to understand changes in logistics systems and the underlying drivers and be able to improve the attractiveness of their location. 


\section{REFERENCES}

Abrahamsson, M. (2003), Logistics Platforms for improved Strategic Flexibility, International Journal of Logistics: Research and Applications, vol. 6., no. 3.

Bowersox, D.J. (1978), The Logistics of the last Quarter of the $20^{\text {th }}$ century, Journal of Business Logistics, , vol. 1, no. 1, pp. 1 - 9.

Buck Consultants International (1999), Sectorstudie Distributie, Arnhem.

Buck Consultants International (2001), From EDC to ELC - more value added through smarter logistics, HIDC, Arnhem.

Buck Consultants International (2003), Excellent Logistiek, HIDC, Arnhem.

Carbone, V. and M. de Martino (2003), The changing role of ports in supply-chain management: an empirical analysis, Maritime Policy and Management, vol. 30, no. 4 pp. 305-320.

Chang, Y-T (2003), Overview of Korea's Strategic Plan to be Logistics Hub in Northeast Asia: Issues and Options, Paper for IAPH Regional Meeting 2004, Busan.

Chikan, A. (2001), Integration of production and logistics - in principle, in practice and in education, International Journal of Production Economics, no. 69, pp 129-140.

Cooper, J., Browne, M. and Peters, M. (1990), Logistics Performance in Europe: the challenge of 1992, International Journal of Logistics Management, vol. 1, no. 1, pp. $28-35$.

Daskin, M.S. (1985) Logistics: an overview of the state of the art and perspectives on future research. Transportation Research, vol. 19A, nr. 5/6, pp. 383 - 398.

ERBS (2002), Policy and Implement Strategy for development of Logistics hub: The case of The Netherlands, Rotterdam.

Fawcett, S.E. (1992), Strategic Logistics in co-ordinated global manufacturing success, International, Journal of Production Research, vol. 30, no. 4, pp. 1081 - 1099.

HIDC (1994), Nippon Traffic - Japanese companies in Europe, chances for The Netherlands as value added Gateway, Zoetermeer.

HIDC (2001), The Netherlands, Excellence in integrating supply chain capabilities, Zoetermeer.

Huybrechts M., Meersman, H., Van de Voorde, E., Van Hooydonk, E., Verbeke, A. and Winkelmans, W., (2002), Port Competitiveness, De Boeck Ltd., Antwerp.

Larson, P.D. and A. Halldorsson (2004), Logistics versus Supply Chain Management: An International Survey, International Journal of Logistics: Research and Applications, vol.7, no.1.

Panayides, Ph. M. (2004), Logistics service providers: An empirical study of marketing strategies and company performance, International Journal of Logistics: Research \& Applications, Vol. 7, No. 1, pp. 1-15.

Rimmer, P.J. (2003), Freight Logistics: A new Area for Cooperation between Korea and Australia, Journal of International Logistics and Trade, vol. 1, no 1, pp. 55-69.

Ruijgrok, C.J. and B. Kuipers (2001), Transportation Infrastructure Management for attracting European Distribution Centres in the Netherlands, Working paper.

Welters, H.W.H. and De Langen, P.W. (2002), Haveneconomie in de praktijk, Syllabus Erasmus University Rotterdam, Rotterdam. 
Welters, H.W.H. and De Langen, P.W. (2003), Het onzekere voor het zekere nemen, Reed

Business Information Transport, Rotterdam. 